\title{
Pentru o istorie a punctuației românești
}

\author{
Adina Chirilă \\ Facultatea de Litere, Istorie și Teologie, Universitatea de Vest, Bd. Vasile Pârvan 4, 300223 Timişoara, România
}

\section{Despre articol}

Istoric:

Primit 17 noiembrie 2015

Acceptat 30 noiembrie 2015

Publicat 12 februarie 2016

Cuvinte-cheie:

editarea textelor

filologie

\begin{abstract}
Rezumat
În practica realizării edițiilor academice pentru textele românești din epoca veche și premodernă, chiar atunci cînd se înregistrează cu scrupulozitate, în aparatul critic, și sînt comentate în ample studii lingvistice și filologice variantele fonetice, morfologice, sintactice și lexicale pe care le cunoaște un text, erorile grafice, omisiunile și interpolările ș.a., problema punctuației este rezolvată în mod tacit, prin adăugarea unei punctuații sintactice raționale, după norma modernă. Procedeul are unele avantaje pentru cititorul de azi, însă, în fapt, falsifică textul, întrucît pune pe seama autorului originar, fie și neintenționat, faptele unui agent secundar: editorul. În plus, inexistența la noi a releveelor arheologice perfecte ale acestor texte-care să pună în evidență și habitudinile mai mult sau mai puțin conștientizate și constante ale scribilor din vechime-face imposibilă, deocamdată, alcătuirea unei istorii a punctuației românești. Rămîne aceasta un deziderat însă, a cărui realizare depinde de reevaluarea obiectivă a practicii editoriale contemporane.
\end{abstract}

Cercetări complexe de neurolingvistică au pus în evidență faptul că, în timpul lecturii intime, în tăcere, a unui text structurat în concordanță cu normele moderne de redactare, imaginea vizuală a unităților lingvistice din rîndul tipografic (și, într-o anumită măsură, manuscris) se înregistrează și se decodifică la nivelul cortexului mai repede decît corespondenta ei sonoră, urmînd unor particularităţi cognitive individuale atît înnăscute, cît și deprinse și perfectibile. Ritmul lecturii poate fi perturbat însă de variabile textuale (e.g., grade diferite de complexitate conceptuală a discursului, elemente care depășesc aria de previzibilitate conturată de constructul sintactic și semantic parcurs anterior etc.-ceea ce determină o durată de fixare oculară mai mare, o scădere în amplitudinea mișcărilor intermitente ale ochiului și creșterea frecvenței regresiilor, Rayner \& Pollatsek, 1989, Rayner, 1998) și tipografice (alternarea tipurilor de literă, lungimi diferite ale rîndurilor, omiterea ori implicarea eronată-în raport cu norma-a simbolurilor punctuației: pauza dintre cuvinte, virgula ș.cl.). Studiile de acest tip demonstrează că efortul milenar al scribilor și al tipografilor de a spori accesul la conținutul cărților a avut ca rezultat nu doar simplificarea procesului neurofiziologic al lecturii (prin renunțarea, bunăoară, la scriptio / scriptura continua și introducerea mărcilor vizuale ale punctuației), ci și o progresivă condiționare a performanței în actul receptării și comprehensiunii textului. Astfel, cititorul nu poate fi decît omul epocii sale și al contextului în care evoluează, format pentru întîlnirea la nivel optim cu un text construit în deplină concordanță cu normele grafice contemporane sau cu cele convenționale într-un mediu specific. Orice mise en page nestandardizată se constituie, perceptiv, într-o anomalie; care, eventual și în anumite circumstanțe (i.e. literare), poate fi recuperată stilistico-estetic (Vianu, 1968, p. 50-51) (v., e.g., pictogramele sau ideogramele lui Apollinaire, experimentele tipografice ale lui Mallarmé, explorările estetice ale lui Beckett și, în ultima decadă, jocurile literare desfăşurate într-un număr limitat de caractere, pe ecranele telefoanelor mobile-Crystal, 2008, p. 74-86), dar care, altminteri, prezintă o dificultate pentru lector.

Din acest punct de vedere, întîlnirea dintre un cititor şi un text aparţinînd unei epoci diferite necesită în mod firesc ajustarea uneia dintre entități în direcția celeilalte: fie prin renunțarea de către prima la prerogativul de confort al lecturii, fie prin eliminarea de către cea de-a doua a unora dintre elementele ei

*Adresă de corespondență: chiriladina@yahoo.com. 
specifice constituente. În ambele situații, procesul presupune amputarea unui organism suficient și perfect într-un context, însă nefuncțional ori doar parțial funcțional în altul.

Istoria receptării textelor culturii universale, de la un secol la altul, arată că, de obicei, în relația carte cititor, cea care este „sacrificată”, supusă adaptării, este prima, cazurile extreme și la îndemînă înregistrînd în rîndul lor ediții prescurtate ale poemelor Antichității, prelucrări lingvistice ale operelor vernaculare din Evul Mediu tîrziu ori din zorii modernității, relevante oricînd pentru spiritul uman, însă devenite obscure din pricina evoluția limbii, etc.--demersuri apărate de către inițiatorii lor cu mai puțină sau mai multă îndreptăţire. Acestea dar și cele care presupun intervenții mult mai mici în morfologia textului au drept miză salvarea textului respectiv în conștiința cititorului generic, a textului simplu ori a textului, pur și simplu.

Totuși, un text nu este niciodată doar un text și cu siguranță nu este un text pur și simplu. Aspectul său originar, pe diverse planuri, reprezintă măsura putinței și a nevoilor unei epoci; originea textului, variantele pe care le cunoaște ori, dimpotrivă, singularitatea lui, identitatea agenților care au produs textul în sine și au operat asupra acestuia, motivele călăuzitoare etc. orientează felul în care este citit acel text și, în consecință, în care este preluat mesajul său (Shillingsburg, 2006, p. 33). Orice intervenție asupra textului îl apropie de unul valabil și important pentru epoca în care este operată aceasta, dar îl rupe, inevitabil, de contextul care l-a generat.

În lumina aceasta, editarea într-un fel oarecare a unui text din epocile trecute apare în primul rînd ca rezultat al temeinicei cumpăniri între cîștigul pe care l-ar simţi cititorul modern și pierderea suferită de text. Cînd se consideră că cel dintîi are o greutate mai mare (prin natura informației conținute de text, prin valoarea morală ori etică a mesajului, prin caracterul fondator într-un domeniu spiritual ori intelectual etc.), editarea se va pune în slujba cititorului; în alte situații însă, trebuie să prevaleze textul ca oglindă a epocii ce l-a generat. Astfel, problema dacă unui anumit text i se consacră efortul alcătuirii unei ediții academice în cel mai sever sens cu putință ori „doar” a unei foarte bune ediții de popularizare este oarecum greșit pusă și trece peste o întrebare prealabilă: dacă textul respectiv ar contribui la cunoașterea generală, astfel încît să fie justificată intervenția la nivelul formei (punctuație, segmentare, întregirea prescurtărilor, uniformizare grafică ș.a.), în vederea obținerii accesibilității lui (argument invocat îndeobște), cu prețul pierderii (ori, în cazul fericit, al trecerii în plan secund, în aparatul critic) aspectului său originar.

Alături de litere și accente (esențiale în sistemele grafice ale unor limbi ca elena ori franceza, mai puțin importante în română, de exemplu), punctuația este parte a codurilor lexicale ale unui text (acestea, diferite de codurile bibliografice - tipul de literă, distribuția spațiilor albe, legătura cărții etc.), de care depinde lectura textului ${ }^{2}$. Instituirea, dezvoltarea și rafinarea ei începînd cu secolul al VI-lea - al VII-lea d.Ch. ${ }^{3}$ în discursuri ce se adresau minții prin văz (Parkes, 2012, p. 1), au stat sub semnul nevoii de claritate și ușurință, mai întîi în privința parcurgerii și stăpînirii textului latin, apoi ale celui vernacular. Admițînd că, trecînd dintr-un spațiu cultural în altul, nu pot fi generalizate observațiile privind istoria punctuației în Europa, ci trebuie să se țină seama de specificul evoluției fiecărei arii în parte ${ }^{4}$, rămîn totuși cîteva aspecte pe care nu

\footnotetext{
${ }^{1}$ Înțelegem astfel cît de pertinentă ar putea fi ideea realizării unei ediții modernizate a operei lui Dimitrie Cantemir Istoria ieroglifică, de exemplu, cu o gramatică adaptată normelor literare actuale.

${ }^{2}$ Răspunzînd unei corespondente care-l întrebase cum să-și crească fiica, Ieronim îi dă următorul sfat (în epistola 107.12, Ad Latam, de institutione filix), sintetizind foarte bine grija pentru acuratețe a grămăticului timpuriu: „Pro gemmis aut serico diuinos codices amet, in quibus non auri et pellis Babyloniæ uermiculata pictura, sed ad fidem placeat emendata et erudita distinctio.” [,În locul nestematelor şi al mătăsii, să iubească sfintele Codice în care nu e viermuita sulemenire a aurului şi a măştii babiloniene; ci pentru credință să-i placă îndreptata şi învăţata podoabă.” (trad.: dr. Dan Negrescu); cf. fr.: « Au lieu des gemmes et de la soie, qu'elle aime les volumes divins. C'est pas dans la mosaïque enluminée d'or ou de cuir de Babylone qu'elle cherche son plaisir, mais dans la netteté correcte et savante des textes. » (St. Jérôme, 1955, p. 156); v. Idem, p. 212, nota $P$. 156, l. 19: « Cette netteté s'obtient surtout par la ponctuation, à qui convient spécialement le mot distinctio » / Engl. "Instead of jewels or silk let her love the manuscripts of the Holy Scriptures, and in them let her prefer correctness and accurate arrangement to gilding and Babylonian parchment with elaborate decorations." (St. Jérôme, 1933, p. 364/365); subl.n., A.C.].

${ }^{3}$ Sporadice exemple de punctuație, prin punct sau spațiu între cuvinte, ori o combinație între acestea două pot fi întîlnine în papirusuri ce au supraviețuit din secolul al III-lea î.d.Ch.

${ }^{4}$ La sfîrșitul anului 1470, Guillaume Fichet adăuga lucrării De Orthographia a lui Gasparino Barzizza de Bergame un mic
} 
le putem nega a priori ansamblului activității medievale de scriere, copiere și tipărire a textelor, din orice parte a continentului: a) că există o justificare pentru maniera în care se face uz de sistemul punctuației în textul lucrat; b) că, de la un moment dat, intervine și în privința punctuației, ca și la nivelul gramaticii și al lexicului tendința de a emenda textul, fie prin introducerea unor semne acolo unde nu existaseră înainte, fie prin înlocuirea unora cu altele, fie, în sfîrșit, prin adoptarea unor caractere tipografice ori tipuri manuscrise în acord cu modernizările epocii; c) că pot opera două sisteme de punctuație, cel retoric și cel sintactic, și că, cel puțin în cazul unora dintre autori, există conștiința aplicării unuia dintre ele, mai mult sau mai puțin consecvent.

A pleca de la aceste premise, oricît de neverosimilă ar părea pertinența lor pentru spaţiul românesc, nu este mai nociv decît a pleca de la ideea că, pentru a ușura accesul la conținutul textului pentru cititorul modern (probabil nu atît de interesat pe cît îl dorim), editorul va adăuga tacit textului o punctuație rațională (pe măsură ce parcurge textul, conform înțelegerii sale ori ghidat, în cazul textului biblic, de ediții canonice contemporane, pentru uzul larg), ,în lipsa totală de punctuațiune sau în locul celei greșite din mss" (Russo, 1912, p. 61-62).

Urmînd unei concepții în acord cu înțelegerea editării textelor ca practică a respectării intenției auctoriale, îndreptată așadar spre trecut, editorii atrag constant atenția asupra necesității de a desfășura judecata despre forma textului prin prisma evoluției limbii de pînă la momentul realizării lui ori a posibilităților imediate de evoluție. Evaluarea unei forme oarecare drept greșită sau corectă se face, în consecință, în prezența și sub autoritatea unei norme, care o poate depăși pe cea a textului, a graiului sau a ariei culturale reprezentate de text ori de autor, dar reală în vremea aceea. În privința punctuației, nu există un organism de control asemănător pentru epoca veche românească. Ceea ce deschide drum înspre tratarea ei în respectivele texte în maniera elementelor din codul bibliografic, avînd ca reper regulile punctuației sintactice moderne. Demersul poate fi justificat prin ideea că semnele de punctuație care jalonează sintaxa unui text sînt oarecum redundante, ele apar acolo unde semantica textului, conturată deja, o cere; astfel, editorul modern nu ar face decît să scoată la suprafață ceva deja existent în adîncimea textului, nu să îl falsifice (după cum s-ar întîmpla prin omogenizare sau modernizare fonetică sau gramaticală). Totuşi, viziunea aceasta (manifestată radical la Stein, 1985, p. 214-222) nu reprezintă, pentru textul în sine, o motivare mai puternică înspre emendarea punctuației decît înspre păstrarea ei ca atare.

Adverbul tacit descrie o metodă editorială expusă criticii, întrucît estompează granițele dintre munca scriptorilor și munca editorilor-ansamblul de date obiectiv și judecata editorială subiectivă (Draguet, 1977) —, aducînd la nivelul textului originar ceea ce a fost—altminteri, în mod legitim—modificat, adăugat sau omis de către editor. Nu intră deci în discuție oportunitatea intervenției (obligatorie în realizarea unui tip de ediție nimit critic, v. Chiari, 1951, chiar dacă demersul poate fi grevat de incertitudine atunci cînd editorul are de redat arhetipul sau textul originar, ori cînd are de ales dintre mai multe conjecturi posibile), ci existența prerogativului de a pune pe seama autorului, fie și neintenționat, faptele unui agent secundar.

În privința punctuației din edițiile academice consacrate textelor românești din epoca veche, știm,

tratat despre semnele de punctuație și corecta lor întrebuințare, al lui Guarini de Vérone, iar la Paris, în secolul al XVI-lea, tipografii umaniști Simon de Colines, Geofroy Tory, Christian Wechel, Robert Estienne își puneau temeinic problema calității reproducerii de texte latine, grecești, ebraice și franceze în atelierele lor, atenți la ortografie, gramatică, accente și punctuație, precum și la perfecționarea formei caracterelor tipografice (Perrousseaux [s.a.], p. 223); cam în aceeași perioadă, Scrisoarea lui Neaç̧u nu etalează semne de punctuație propriu-zise, ci doar un punct separator între cuvinte ori secvențe ceva mai lungi, căruia nu i se poate atribui o funcție textuală reală; în PH, folosirea semnelor de punctuație (punctul, virgula și două puncte) „este, în general, arbitrară” (Gheție \& Teodorescu, 2005, p. 35); iar în CB, distribuția lor, generatoare de ambiguități, atrage concluzia că „nu se poate ști cu certitudine la ce serveau aceste semne sau ce marcau ele într-un astfel de text” (Gafton, 2003, p. XLV, nota 55; cf. p. XLVI, nota 57); etc. 
printr-o convenție centenară, că nu o reflectă pe cea a paginii originare ${ }^{5}$, fapt devenit în asemenea măsură de la sine înțeles și normal, încît fundamentalele și amănunțitele intervenții teoretice în cîmpul filologiei ale lui Onu (1973, 1978), Gheție \& Mareș (1974) nu cuprind vreo referire la problema punctuației și, implicit, la dreptul editorului de a o normaliza. A ști însă că nu știm ceva nu reprezintă deloc rezolvarea problemei, căci cititorul iscoditor, care și-ar pune vreodată întrebarea despre configurația originară a punctuației, se vede nevoit să reia munca editorului, parcurgînd din nou textul în grafia veche, travaliul predecesorului său de a translitera sau transcrie interpretativ textul fiindu-i inutil. Cîșsigul de care se bucură cititorul de rînd se traduce într-o pierdere, nu lesne recuperată, a specialistului. S-ar putea aduce la acest punct de vedere obiecția că, realizînd o ediție critică, editorul a analizat deja și acest aspect al textului, evaluîndu-l ca accidental (Greg, 1966, p. 376) ori substanțial (Parkes, 1998, p. 337), operînd asupra lui în consecință. Totuși, cînd interpretarea este insuficient demonstrată sau cînd nu este documentată decizia de a ignora „falsa” punctuație a originalului, apare necesitatea de a fi reexaminat materialul de lucru.

Abandonarea unor elemente din modelul de realizare a edițiilor descris de Hasdeu (1878, p. 3-4) și, mai tîrziu, reticența filologilor români de a adopta principiile drastice ale editării de tip diplomatic ale lui François Masai $(1950)^{6}$ ș.a. au drept consecință inexistența la noi a releveelor arheologice perfecte ale textelor din epoca veche și premodernă—ce ar constitui, fiecare în parte, baza unei ediții critice mai mult sau mai puțin amănunțite; ori, constituindu-se într-un corpus obiectiv—temeiul realizării unor lucrări privind, de pildă, istoria punctuației în scrisul românesc (cf. Parkes, 2012) sau istoria receptării unui text multiplicat prin manuscrise, cu punctuaţie modificată, augmentată ori redusă de la o copie la alta, etc.

Motivul acestei direcții, care a lăsat prea puțin loc editării diplomatice, ține, în mod just, de nevoia de a recupera pentru public cultura scrisă românească din epoca veche și premodernă, într-o luptă mereu perdantă cu timpul; or, adoptîndu-se modelul Școlii belgiene de filologie, conceput de Fr. Masai, L.M.J. Delaissé, H. Vanderhaven, al genevezului Charles Samaran ori cel decelabil din mai recentele teorii ale lui D.F. McKenzie (2002) și Jerome McGann (1983) etc., realizarea edițiilor critice și a celor de popularizare ar reprezenta, ca etapă, pornind de la corpul oferit de ediția diplomatică, demersuri secundare-(prea) tîrzii, în unele circumstanțe.

Dorința cristalizării istoriei punctuației românești rămîne, deocamdată și, probabil, pentru multă vreme, imposibil de realizat. Lipsește acel corpus în care să poată fi urmărită, fără impedimentul alfabetului chirilic, practica lingvistică mai mult sau mai puțin conștientizată și constantă a autorilor, copiștilor, diortositorilor și tipografilor din epoca veche și premodernă-înainte ca vreun model de interpungere să fie descris, chiar sumar şi cu o terminologie șovăielnică, în primele gramatici românești, de către Dimitrie Eustatievici Braşoveanul (1757), Constantin Diaconovici-Loga (1822), Ion Heliade Rădulescu (1828), Timotei Cipariu (1877).

\section{Bibliografie}

Barbu, V. (1988). Probleme și orientări în editarea literaturii medievale, în „Limba română”, XXXVII, nr. 3, p. 143-153. $\mathrm{CB}=$ Codicele Bratul. Ediție de text de Alexandru Gafton, Iași, Editura Universității „Alexandru Ioan Cuza”, 2003.

Chiari, A. (1951). La edizione critica, în Problemi ed orientamenti critici di lingua e di letteratura italiana. II. Tecnica e teoria letteraria, Milano.

Cordingley, A. (2006). The Reading Eye from Scriptura Continua to Modernism: Orality and Punctuation between Beckett's L'Image and Comment c'est / How It Is, în „Journal of the Short Story in English. Les Cahiers de la Nouvelle”. Special issue: Orality in the Short Story in English, nr. 47, Presses De L'Université D’Angers, p. 49-63.

Crystal, D. (2008). Txtng. The Gr8 Db8, Oxford University Press.

Draguet, R. (1977). Une méthode d'édition des textes syriaques, în Robert H. Fischer (ed.), A Tribute to Arthur Vööbus: studies in early Christian literature and its environment, primarily in Syrian East, Lutheran School of Theology, Chicago, p. 13-18.

\footnotetext{
${ }^{5}$ Cînd nu uităm, totuși: „Citim de obicei textele mai vechi în ediții moderne, fără să ne gîndim prea mult la faptul că punctuația lor este actualizată, modificată conform normelor în curs” (Zafiu, 2006).

${ }^{6}$ Vezi și Drimba (1985, p. 88-90), precum și Barbu (1988, p. 146-148).
} 
Drimba, V. (1985). Ediție diplomatică și ediție critică, în „Memoriile secției de științe filologice, literatură și arte”, Seria IV, tomul VII, p. 85-92.

Gafton, Al. (2003). Studiu filologic la CB, Editura Universității „Alexandru Ioan Cuza”, Iași, p. IX-CV.

Gheție, I. \& Mareș, Al. (1974). Introducere în filologia românească. Probleme, metode, interpretări, Editura Enciclopedică Română, București.

Gheție, I. \& Teodorescu, M. (2005). Studiu lingvistic la PH, I, Editura Academiei Române, București, p. 23-75.

Greg, W.W. (1966), Collected Papers, Oxford University Press.

Hasdeu, B.P. (1878). Cuvente den bătrîni, I, Tipografia Sicietății Academice Române, București.

St. Jérôme (1933). Select Letters of . With an English translation by F.A. Wright, London, New York.

St. Jérôme (1955). Lettres. Tome V. Texte établi et traduit par Jérôme Labourt, Paris, «Les belles lettres».

Masai, Fr. (1950). Principes et conventions de l'édition diplomatique, în „Scriptorium”, IV, fasc. 2, p. 177-193, CrossRef.

McGann, J.J. (1983). A Critique of Modern Textual Criticism, University of Chicago Press, Chicago, IL.

McKenzie, D.F. (2002). Making Meaning: "Printers of the Mind" and Other Essays, University of Massachusetts Press, Amherst.

Onu, L. (1973). Critica textuală și editarea literaturii române vechi. Cu aplicații la cronicarii Moldovei, București.

Onu, L. (1978). Tehnica editării textelor românești vechi, în Elena Barborică, Liviu Onu, Mirela Teodorescu, Introducere în filologia română. Orientări în tehnica cercetării științifice, București, Editura Didactică și Pedagogică (ed. I, 1972).

Parkes, M.B. (1998). Medieval Punctuation and the Modern Editor, în Filologia classica e fllologia romanza: esperienze ecdotiche a confronto. A cura di Anna Ferrari, Centro Italiano di Studi sull'Alto Medioevo, Spoleto, p. 337-349.

Parkes, M.B. (2012). Pause and Effect. An introduction to the History of Punctuation in the West, Ashgate (ed. I, 1992).

Perrousseaux, Y. [s.a.]. Histoire de l'ecriture typographique de Gutenberg au XVIIe siècle, Atelier Perrousseaux, [s.l.].

PH = Psaltirea Hurmuzaki, I, studiu filologic, studiu lingvistic și ediție de Ion Gheție și Mirela Teodorescu, București, Editura Academiei Române, 2005.

Rayner, K. \& Pollatsek, A. (1989). The Psychology of Reading, Prentice Hall, Englewood Cliffs, NJ, CrossRef.

Rayner, K. (1998). Eye Movements in Reading and Information Processing: 20 Years of Research, în Psychological Bulletin, vol. 124, nr. 3, p. 372-422, CrossRef.

Russo, D. (1912). Critica textelor și tehnica edițiilor, București, Socec \& Co.

Saenger, P. (1997). Space Between Words: The Origins of Silent Reading, Stanford University Press.

Shillingsburg, P.L. (2006). From Gutenberg to Google. Electronic representations of literary texts, Cambridge University Press.

Stein, G. (1985). Lectures in America, Beacon Press, Boston.

Vianu, T. (1968). Cercetarea stilului, în Studii de stilistică, Editura Didactică și Pedagogică, București, p. 41-59.

West, M.L. (1973). Textual Criticism and Editorial Technique (applicable to Greek and Latin texts), B.G. Teubner, Stuttgart. Zafiu, R. (2006). Din istoria punctuației, în „România literară”, XXXIX, nr. 48. 